\title{
THE RELIGIOUS IDEAS AND METHODS OF WORK IN GURDZHIYEV'S DOCTRINE
}

\author{
(C) Igor M. Grekov \\ Ryazan State University, Ryazan, Russian Federation \\ science-almanac@mail.ru
}

The purpose of this article is consideration of Gurdzhiyev's interpretation of a concept spiritual work and of methods of this work. The author emphasizes that studying Gurdzhiyev's theory of the person, the system of movements and meditation techniques, the interrelation of anthroposophy of "The Fourth Way" and esoteric forms of Christianity many of Gurdzhiyev's followers were direct participants of the events of life in Gurdzhiyev's groups not only theoretically, but also practically. The sphere of their interests led to the research of such problems as "internal and external human life", "mechanics of human behavior", "work", etc. The author claims that Gurdzhiyev's system of "self-improvement" is of considerable interest in today's world and demands judgment in the context of religious and philosophical knowledge. The article gives several problems that, according to G.I. Gurdzhiyev, an ordinary person should certainly face if he does not realize his own "mechanicalness." The author reveals the essence of "The Fourth Way" of G.I. Gurdzhiyev, speaks of his religious and philosophical origins, writes about the need for preliminary preparation before using this methodology. The article also refers to the "point of support" from which the transformation of the inner spiritual world of the person should begin, lists the specific methods that the person who wants to comprehend the doctrine of G.I. Gurdzhiyev about "The Fourth Way" should use. The author emphasizes the need for daily "work on himself," and also details the obstacles that can prevent the person from achieving the desired result. The author lists seven areas of "internal work on himself," which can be found in the works of G.I. Gurdzhiyev, justifies the advantage of the anthroposophical system of G.I. Gurdzhiyev in comparison with other philosophical directions.

Key words: work, internal work, introspection, intentioned suffering, remorse, self-reminiscence, selfawareness.

\section{[И.М. Греков Религиозные идеи и методы работы в гурджиевском учении]}

Целью данной статьи является рассмотрение гурджиевской интерпретации понятия духовная работа и методов данной работы. Автором подчеркивается, что, изучая гурджиевскую теорию человека, систему движений и медитативных практик, взаимосвязь антропософрии «четвертого пути» и эзотерических форм христианства не только теоретически, но и практически, многие из последователей Гурджиева были непосредственными участниками событий жизни в гурджиевских группах. Сфера их интересов привела к исследованию таких проблем как «внутренняя и внешняя жизнь человека», «механики человеческого поведения», «работа» и др. Автор утверждает, что гурджиевская система «работы над собой» представляет значительный интерес для современности и требует осмысления в контексте религиозно-философского знания. В статье приводится несколько проблем, с которыми, по мнению Г.И. Гурджиева непременно должен столкнуться обычный человек, если он не осознает собственной «механичности». Автор раскрывает суть «четвертого пути» Г.И. Гурджиева, говорит о его религиозно-философских истоках, пишет о необходимости предварительной подготовки перед использованием данной методики. В статье также говорится о «точке опоры», с которой должно начаться преобразование внутреннего духовного мира человека, перечисляются специфические методы, которые следует использовать человеку, желающему постигнуть учение Г.И. Гурджиева о «четвертом пути». Автор подчеркивает необходимость ежедневного «труда над собой», а также подробно описывает препятствия, которые могут помешать человеку достичь желаемого результата. Автор перечисляет семь направлений «внутренней работы над собой», которые можно встретить в трудах Г.И. Гурджиева, обосновывает преимущество антропософрской системы Г.И. Гурджиева в сравнении другими философскими направлениями.

Ключевые слова: работа, внутренняя работа, самонаблюдение, намеренное страдание, угрызение совести, самовоспоминание, самоосознание. 
Igor M. Grekov - Ph.D. in Philosophy, Ryazan State University, Ryazan, Russian Federation.

Греков Игорь Михайлович - кандидат фрилософрских наук, Рязанский государственный университет, е. Рязань, Российская Федерация.

The researches of Gurdzhiyev's anthroposophy conducted in the West have become opened and relevant for Russia at present. Many works are translated into Russian and published. The St. Petersburg publishing house "Ves" headed by Pyotr Lisovsky published a series of books "The Fourth Way" which included the works of Gurdzhiyev's followers and pupils. Among them, first of all, it is necessary to note Pyotr Demyanovich Uspensky (18781949), Boris Petrovich Muravyev (1890-1966), John Godolfin Bennett (1897-1974), Maurice Nicol (1884-1953), Charles Stanley Nott (1887-1978), Rodney Collin (1909-1956), Robert Earl Burton (1936). It is not the full list of thinkers, in the focus of attention and judgments of which there is Gurdzhiyev's doctrine about the person where the idea and methods of spiritual work are revealed.

The main Gurdzhiyev's idea when the person does not possess individual, constant, invariable and unified "I" and he is split on a set small "I", is accepted by all the followers of "The Fourth Way". The person is defined as "plurality, the name of which is a legion". Instead of unified "I" in the person there are hundreds separate small "I", quite often incompatible. Every separate "I" call oneself by the name of the whole. The person believes in his "last I" which acts on behalf of the whole. Forgetting about it in an hour, he can approve the opposite opinion, point of view and judgment with the same conviction. At any time, pleasant emotions can turn into unpleasant: love to hatred, joy to irritation, etc. The change of external circumstances, the change of impressions of what is warm and comfortable, cold, good and clear weather cause one group of "I", and cold and rain cause another, with other associations, feelings and actions. To control the change of "I" is almost impossible for the being in the last "l" in the situation when this shift is not noticed and not realized. As a result, the person is considered as the "machine" reacting to the external circumstances. The ideas and practice exercises for overcoming the given "horror-situation" are presented in Gurdzhiyev's doctrine and movement. It is necessary to pay attention to the origin of the title "The Fourth Way". Quoting G.I. Gurdzhiyev, P.D. Uspensky (Uspensky, 2010) writes that all the ways to the immortality of (the soul) can be divided into three categories: the way of the fakir, the way of the monk and the way of the yogi. The way of the fakir (the first way) assumes the performance of physical exercises, the torture of the body, the development of physical will, the achievement of the power over the body. The way of the monk (the second way) is the way which is followed by the person with strong religious emotions spending forces for the fight against himself, his feelings for the purpose to subordinate all the emotions to one - belief. A part of work on the way of the monk consists in full obedience to the teacher, but the main thing is a faith in God, love for God and service of God (about specifics of the relations between the Teacher and the pupil in the East tradition: Trubnikova N.N., 2017; Kozhevnikova M.N., 2018; Pskhu R.V., Kryshtop L.E., 2018). The third way, the way of the yogi, the way of knowledge is the way on which the person develops his intellect, understanding his condition and realizing the need of development of his physical body and emotions (about the idea of intellect in the Buddhism: Tkhupten Dzhinpa Lengri, 2017). There is a common feature which unites these three ways: the movement on these ways begins with full renunciation by the person of everything "worldly", he has to "die" for the world, having gone to the desert, to the monastery, to school of yoga.

"The Fourth Way" is not a simple combination of ways of the fakir, the monk and the yogi. It does not demand from the person of refusal of the "worldly" life, of family, profession, 
friends and relatives, i.e. the external refusal of things is not required, as all the work (efforts on conscious transformation of himself) has internal character.

"The Fourth Way" is a spiritual direction of conscious evolution of the person according to which the disclosure of human essence begins with understanding of "the imperfect nature" and also the present possibility to eliminate this "imperfection", to carry out individual evolution in the course of knowledge of oneself, to reach the change of level of life and consciousness by means of elimination in oneself negative intellectual, emotional, instinctive and motional manifestations.

The founder of "The Fourth Way" was G.I. Gurdzhiyev whose ideas about the person and the Universe were distributed among his pupils and followers as a result of their direct interaction with the teacher and were transferred as an oral tradition.

The doctrine of "The Fourth Way", practical methods which G.I. Gurdzhiyev had used for the purpose of harmonization of the inner world, evolutions of human opportunities, sometimes are compared to many traditional teachings, and first of all to Sufism. However, the idea of work with the purpose of self-discovery is also presented in more ancient teachings. Uspensky, stating the content of the lecture of G.I. Gurdzhiyev "Learn yourself!" writes: "These words, Gurdzhiyev told, ordinary attributed to Socrates, in practice are the cornerstone of many systems and schools, much more ancient than Socratic school. In spite of the fact that the modern thought knows of the existence of this principle, it has a very obscure view of its sense and value. The ordinary person of our time, even having philosophical and scientific interests, does not understand that the principle "Learn yourself!" tells about the need of learning of the own machine, "the human machine"'" (Uspensky, 2010, 142 p.).

Considering that machines of all people are arranged more or less equally that in the human machine everything is so interconnected and one thing so depends on another, the person has to study the structure, functions and laws of the organism. It is impossible to study some function, for example, only intellectual, out of the question at the same time emotional and instinctive and motional. So that to know one thing, it is necessary to know everything, and this learning is possible, but it demands a lot of time and work, necessary correct methods and correct management.

In the condition in which there is a modern mankind, the person is too far from selfdiscovery, he is absorbed by the external aspects of his life. "Self-discovery" turns into vague and far purpose. Self-studying which represents the way leading to self-discovery can become closer and simple purpose. Getting to such work, the person needs to learn at first how to do it, what to begin with, what methods to apply. He has to study the principles of self-studying and to get acquainted with its methods.

\section{Introspection and registration}

Introspection is recognized as the main method in Gurdzhiyev's work. "Practical Esotericism" - Gurdzhiyev's "work", "the spiritual Way conducting the person "inward", to Spirit, to God and to the integrity of life" begin with real introspection, self-discovery and selfstudding (Nezhinsky).

Without correctly applied introspection the person cannot learn connection and ratio between various functions of the machine, he will never understand why in each separate case everything "happens" with him. Observing functions of this machine, at first, it is necessary to learn to distinguish them, to define, relying on the nature of definition of internal experiences. Two methods of introspection are allocated (Uspensky, 2010; Burton, 2011). The first is an analysis, i.e. an attempt to find answers for the questions: why this or that phenomenon happens, why such dependence exists. The second method is a registration, 
just a "record", fixation in mind of what is observed at present. This method is initial. Its use is necessary for the purpose of recognition of all functions of a human body and of all laws which manage the body. Introspection should not become the analysis or the attempt of the analysis at the initial stage of work. Attempts to analyze the separate phenomena without knowledge of the general laws are regarded as useless waste of time in Gurdzhiyev's system. To carry out the analysis even of elementary phenomena, the person has to save up enough material by means of the so-called "record", i.e. fixation of the result of direct observation of this or that phenomenon, happening directly at present.

\section{Intentioned suffering}

Introspection is not "intellectual speculations", it is not self-reflection, and it is not emotionally charged experiences. It is about the ability of the person to recognize himself, watching himself in all his manifestations sincerely and honestly; to stand the stern test of self-exposure to try to find in the internal reality factors on which he could lean firmly in search of knowledge. The conscience, but not in that illusory idea of it, not illusion concerning possession of conscience, but "objective-conscience" (Gurdzhiyev, 2010, 222 p.), in true meaning of this word, in all intrinsic "volume" of this concept has to become this point of support, according to G.I. Gurdzhiyev. "Intentioned suffering" and "remorse" have ability to be transformed to positive emotions of conscience and compassion the formation of which demonstrates the transformation of the person.

Martin Lass, the follower of the ideas of Gurdzhiyev, in the work "Intentioned suffering" notes: "The intentioned suffering means that I can sustain the truth about myself, about my automatism, about my dissociation with essence, about my illusions, ignorance and uselessness. It means the position between, who I am (that actually is not the same who I am, but more what I am and how I am) and whom I Wish to Be" (Lass). The intentioned suffering is caused by what the person sees in himself through conscious work introspection, sense of self, self-reminiscence, in the absence of value judgments, of analysis and of external projection. Introspection and sense of self as two components of conscious work have effect of accumulation which appears between attention and feeling, between the intellect and the body and that is possible to call feeling which completely differs from usual negative emotions. This feeling is the growing sensibleness of the emotional nature of the body. Continuing to work in this direction, the person finds new vision of himself and an opportunity to remain face to face with manifestations of his false personality and the "protection" system which hold him in the condition of a day-dream. This vision causes suffering. It is necessary to experience "own pettiness" so that "to find the Way", to pass "an external fencing", exoteric level, and to pass not intellectually, but in experience, in life, realizing the real situation. This understanding can be revealed to the person as emotionally sharp and long-term suffering, as suffering which the person needs to stand because the way to intentioned suffering begins with it.

There has to be a starting point of Work on oneself. This starting point is now. If the person does not work every day in his life by self-control, by the way of application of the ideas of Work to what he observes, then there is no starting point. The person can hope that he will begin self-improvement tomorrow. However, life breaks up into days and years, and tomorrow never comes. The disease tomorrow is one of the most dreadful diseases of "three-brain beings", according to Gurdzhiyev (Gurdzhiyev, 2010). 


\section{Self-reminiscence}

The book by R. Burton "Self-reminiscence" is devoted to the ability to be present constantly at the present, "to remember oneself (Burton, 2011). Burton notes that during all human life everything remains uncertain, except his present time. However, it is difficult for the modern person to concentrate in the present moment, to hold his thoughts within the present moment, to feel at the present moment. He aspires into the future, or stays in the past infinitely. According to Burton, the main idea which is offered by Gurdzhiyev's system is the idea of self-reminiscence which is absolutely lost sight by the western psychology. He writes that self-reminiscence cannot be imitated, self-reminiscence is not a feeling, and not the talks about self-reminiscence, it is an attempt to be there, "where you are", in the moment. Self-reminiscence is a process of the divided attention at which the attention of the person is concentrated at the same time in two directions: that is out of the person, and that is inside. Thus, the person is open for the world around and at the same time he perceives what occurs inside, feeling his body, realizing the fact that he exists, and he exists directly at present time. This is the work which the person seeking to learn himself needs to do, i.e. observation of himself in the course of intellectual, emotional or physical existence demands certain efforts, in view of complexity to carry out this practice all the time.

\section{Directions of spiritual work}

John Bennett (Bennett, 2001) allocates seven directions of spiritual work on oneself. During the work on the first direction the person studies himself, he is sure of mechanicalness of own life, of the existence of his highest and lowest nature, he gets a chance to be convinced of own "commonness", of deception of himself. The ordinary person in Gurdzhiyev's anthropology is the person connected only with ordinary and practical life which can be called "usual survival". The term "ordinary person" in anthroposophy of "The Fourth Way" is used not in pejorative sense. This phrase does not contain value judgments. This is the person in whom his lowest mental centers dominate: instinctive and motional, emotional, intellectual, and communication with the highest mental centers (emotional and intellectual) either is violated, or is absent. One lowest center of "ordinary person" often reacts instead of another. For example, in the situation when it would be more suitable to react physically, the person reacts emotionally (fear of coming to the stage), or in the situations when the intellectual center has to be involved, the person reacts emotionally: when the person takes examination, having learned all exam papers, but cannot pronounce any word and cannot answer the questions of the examiner. The emotional center, having involved the physical one, block the intellectual center.

The second area of work is a fight against own weaknesses (an internal statement). The third area is a service (a statement in community). Service means the victim, and one of its important forms, the victim in favor of the future. The person has to work today so that the people in the future will have these or those opportunities, and these people, perhaps, will never think of the work of the previous generations. The key concepts here are: I, community, world and action. The concept "world" indicates what is beyond the person and beyond the circle of its communications within the community which includes not only the people who are directly making a circle of contacts at the moment of time. The words "I" and "action" are perceived from the position of concrete experience. Devoting oneself to the service to other people, the person inevitably attracts sufferings. It is the "deliberate suffering" arising because the person assigns to himself the obligations making his suffering inevitable. Working for the sake of others, the person will get the chance to get rid of egoism. The fourth area of work is manifestation (coordination in operation). From the point of view 
of this area of work, the person should not interfere with the action actively or perceptively, the work approves itself. This area is called neutral, in this area active and perceiving (passive) beginnings are absent. Bennett notes that it is possible to come to this area of work, practicing Gurdzhiyev's movements. "The movements represent Work manifestation. If only we find in ourselves an opportunity to leave the way of this process, the movements will show Work in themselves. We allow the movements to make themselves" (Bennett, 2001,142 p.). The fifth is susceptibility (in the community). This area is accompanied by the ability to accept the help. The sixth area is submission (internal susceptibility). This area, according to $\mathrm{J}$. Bennett, is connected with the work "from within to inward", from depth to more superficial, on condition of full and unconditional submission to that spiritual nature that "lies more deeply in ourselves". The seventh area of work is acceptance, purity (susceptibility in the world). It is the ability to be sensitive, susceptible to the spiritual actions filling the world.

The methodological and theoretical basis of the thesis was made of the researches of foreign and domestic scientists: Pyotr Demyanovich Uspensky, Boris Muravyev, Maurice Nicol, John Godolfin Bennett, Charles Stanley Nott, Rodney Collin, Robert Earl Burton, Peter Brook, Charles Tart.

The tools for identification of specifics of anthroposophy of "The Fourth Way" are the comparative-historical and contrastive-comparative methods allowing to draw historical parallels, analyzing features of Gnostic traditional teachings and "The Fourth Way" as an experience of search of Gnostic tradition in the 20th century.

The research is based on the use of general scientific methods among which there are methods of empirical description, comparison, classification, analysis and generalization.

\section{Conclusion}

In the conditions of dissociation of approaches and positions in the anthropological thought there is a need of the appeal to the anthroposophic systems designed to fill onesidedness of such directions as psychoanalysis (in many respects absolutizing a role of unconscious processes), the behaviorism (concentrating on behavioral aspect of human existence), the existentialism (emphasizing hopelessness "abandonment of life in the world"). One of such systems is Gurdzhiyev's system of conscious evolution of the person, the so-called "The Fourth Way" which is eligible for the status of the translater of the experience of Gnostic tradition in present period.

"The Fourth Way" is a spiritual direction of conscious evolution of the person according to which disclosure of human essence begins with understanding of "the imperfect nature" and also in the present possibility to eliminate this "imperfectiveness", to carry out individual evolution in the course of knowledge of oneself, to reach the change of the level of life and consciousness by means of elimination in oneself negative intellectual, emotional, instinctive and motional manifestations by means of work.

Work in Gurdzhiyev's system (in a general sense) is the efforts made by the person for the purpose of implementation of spiritual transformation, completion of internal evolution, realization of chance of self-development. In a narrow sense work is a set of practical methods, spirituality, exercises, movements, meditations promoting harmonization of the inner world.

In general, Gurdzhiyev's system is an attempt to exempt the person from heavy freight of laws under which the mankind forces to live his place in the Universe. This technique consists in prevention of leakages of energy and "setting of the machine" for transformation of different types of food to which air, water, food and impressions belong. 
Gurdzhiyev's work is intended to bring the person closer to understanding of "horror of life of the ordinary people" absorbed by circulation of interests, affairs and purposes which enslave, imprisoning everyone in own prison, thereby, limiting the search of spiritual freedom.

Gurdzhiyev's work does not demand withdrawal from "world", it can proceed in the conditions which are daily for the person: his environment, family, profession, habits and duties. Conditions in which the person exists at present, at the moment, are considered as optimum to start transformation and work with the purpose of learning of himself and of the world. The person is capable to observe the habitual functioning in daily conditions, analyzing it in terms of misoperation of the centers and to some extent changing it. In this context, perhaps, "The Fourth Way" also seems more available, than other ways of spiritual self-development, but it demands from the person of his own strong-willed efforts, internal motivation.

Work on conscious transformation of himself has the internal character (introspection, self-reminiscence, self-understanding) and it is directed to receive individual understanding. In this context "The Fourth Way" can be considered as realization of experience of Gnostic tradition in the modern world.

\section{Лumepamypa}

1. Беннетт Дж. Общины нового века. Семь направлений работы. М., 2001.

2. Гурджиев Г.И. Рассказы Вельзевула своему внуку. Объективнобеспристрастная критика людей. М., 2010.

3. Нежинский И.В. Эзотерическое христианство Георгия Гурджиева [Электронный pecypc]. URL: http://www.fway.org/articles/261-2009-03-13-20-35-10.html. (Дата обращения: 25.08.2020).

4. Ласс M. Намеренное страдание [Электронный ресурc]. URL: http://www.gurdjieffclub.ru/ru/glavnaja/resursy-teksty-video ssylki/stati/namerennoestradanie.html. (Дата обращения: 31.08.2020).

5. Успенский П.Д. В поисках чудесного. М., 2010.

\section{References}

1. Bennett J. Obshchiny novogo veka. Sem napravlenii raboty. [Communities of a new century. Seven areas of work]. Moscow, 2001 (in Russian).

2. Gurdzhiyev G.I. Rasskazy Velzevula svoemu vnuku. Obektivno-bespristrastnaia kritika liudei. [Stories by Beelzebub to his grandson. Objective and impartial criticism of people]. Moscow, 2010 (in Russian).

3. Nezhinsky I.V. Ezotericheskoe khristianstvo Georgiia Gurdzhieva. [Esoteric Christianity of Georgy Gurdzhiyev]. Available at: http://www.fway.org/articles/2612009-03-13-20-35-10.html (accessed 25 August 2020).

4. Lass M. Namerennoe stradanie. [Intentioned suffering]. Available at: http://www.gurdjieffclub.ru/ru/glavnaja/resursy-teksty-video ssylki/stati/namerennoestradanie.html (accessed 31 August 2020).

5. Uspensky P.D. In search of wonderful. [V poiskakh chudesnogo]. Moscow, 2010 (in Russian). 